DOE/LLW-213

RECEIVED

NOV 211995

OSTI

Potential Co-disposal of

Greater-Than-Class C Low-Level

Radioactive Waste with

Department of Energy

Special Case Waste

Greater-Than-Class C Low-Level Waste Management Program

September 1994 
DOE/LLW-213

\title{
Potential Co-disposal of Greater-Than-Class C Low-Level Radioactive Waste with Department of Energy Special Case Waste
}

\author{
Greater-Than-Class C Low-Level Waste \\ Management Program
}

\author{
W. E. Allred
}

Published September 1994

\begin{abstract}
Idaho National Engineering Laboratory
EG\&G Idaho, Inc.

Idaho Falls, Idaho 83415
\end{abstract}

Prepared for the

U.S. Department of Energy

Assistant Secretary for Environmental Management

Under DOE Idaho Operations Office

Contract DE-AC07-76ID01570 


\section{DISCLAIMER}

Portions of this document may be illegible in electronic image products. Images are produced from the best available original document. 


\section{ABSTRACT}

This document evaluates the feasibility of co-disposing of greater-thanClass C low-level radioactive waste (GTCC LLW) with U.S. Department of Energy (DOE) special case waste (SCW). This document

- Discusses and evaluates key issues concerning co-disposal of GTCC LLW with SCW. This includes examining these issues in terms of regulatory concerns, technical feasibility, and economics.

- Examines advantages and disadvantages of such co-disposal.

- Makes recommendations.

Research and analysis of the issues presented in this report indicate that it would be technically and economically feasible to co-dispose of GTCC LLW with DOE SCW. However, a dilemma will likely arise in the current division of regulatory responsibilities between the U.S. Nuclear Regulatory Commission and DOE (i.e., current requirement for disposal of GTCC LLW in a facility licensed by the Nuclear Regulatory Commission). DOE SCW is currently not subject to this licensing requirement.

\section{DISCLAIMER}

This report was prepared as an account of work sponsored by an agency of the United States Government. Neither the United States Government nor any agency thereof, nor any of their employees, makes any warranty, express or implied, or assumes any legal liability or responsibility for the accuracy, completeness, or usefulness of any information, apparatus, product, or process disclosed, or represents that its use would not infringe privately owned rights. Reference herein to any specific commercial product, process, or service by trade name, trademark, manufacturer, or otherwise does not necessarily constitute or imply its endorsement, recommendation, or favoring by the United States Government or any agency thereof. The views and opinions of authors expressed herein do not necessarily state or reflect those of the United States Government or any agency thereof. 


\section{SUMMARY}

This document evaluates the feasibility of co-disposing of greater-than-Class $\mathrm{C}$ low-level radioactive waste (GTCC LLW) with U.S. Department of Energy (DOE) special case waste (SCW).

SCW is defined as DOE generated or DOE titled radioactive waste that does not fit into typical management plans developed for the major radioactive waste types [i.e., transuranic (TRU), low-level radioactive waste (LLW), or high-level radioactive waste (HLW)]. SCW can pose problems for generators, handlers, and disposal facility operators because these activities will require specific management and disposal schemes. SCW is primarily waste for which there are limited or no planned disposal alternatives. It includes such a wide variety of forms and isotopic mixtures that, in recent studies, it has been divided into several subcategories.

GTCC LLW is commercial radioactive waste, generated by U.S. Nuclear Regulatory Commission (NRC) and Agreement State licensees, that exceeds the Class $\mathrm{C}$ limits defined in Title 10, Code of Federal Regulations, Part 61 (10 CFR 61). The 10 CFR 61 codifies disposal requirements for three classes of LLW considered generally suitable for near-surface disposal. They are $\mathrm{A}, \mathrm{B}$, and $\mathrm{C}$, with Class $\mathrm{C}$ waste requiring the most rigorous disposal specifications. Waste with concentrations above Class $\mathrm{C}$ limits for certain short- and long-lived radionuclides is identified as GTCC LLW. Federal law requires that DOE ensure safe disposal of GTCC LLW in a disposal facility licensed by the NRC.

The term GTCC LLW is often incorrectly applied to DOE-generated or DOE-titled waste. Such wastes that have concentrations above Class $C$ limits and that do not fit into typical DOE waste management plans, are included within certain subcategories of SCW.

The focus of this report is to discuss and evaluate issues concerning co-disposal of GTCC LLW with SCW in terms of regulatory concerns, technical feasibility, and economics. In addition to this main focus, the report presents an in-depth background on SCW and GTCC LLW and discusses their similarities.

Research and analysis of issues presented in the report indicate that it would be technically feasible and economical to co-dispose of GTCC LLW with SCW. The following points bring this to light.

- $\quad$ Almost half $\left(411,785 \mathrm{~m}^{3}\right)$ of the total $993,044 \mathrm{~m}^{3}$ of SCW has waste characteristics similar to those of GTCC LLW $\left(3,638 \mathrm{~m}^{3}\right)$. Co-disposal is reasonable when one realizes that DOE needs to manage and dispose of large volumes of $\mathrm{SCW}$ with waste characteristics similar to those of GTCC LLW. The total estimated volume of SCW is many times more than the total estimated volume of GTCC LLW.

- The cost factor in the life cycle of a disposal facility for SCW and/or GTCC LLW should be examined. For example, given the small volume of GTCC LLW $\left(3,638 \mathrm{~m}^{3}\right)$ the estimated cost of disposal of GTCC LLW in a stand-alone, separate facility (intermediate depth or deep geologic) is $\$ 123,599$ per $\mathrm{m}^{3}$ (or $\$ 3,500$ per $\mathrm{ft}^{3}$ ). Compare this with an estimated life-cycle cost of a DOE intermediate-depth disposal facility, 
which could handle SCW and GTCC LLW, of $\$ 43,294$ per $\mathrm{m}^{3}$ (or $\$ 1,226$ per $\mathrm{ft}^{3}$ ). Because of the economy of scale, the life cycle of a disposal facility dedicated to the disposal of GTCC LLW and equivalent SCW would be prorated over a larger volume of waste, thereby reducing the fee per unit volume charged to generators.

- Studies and actual demonstrations on radioactive waste disposal technology suggest that co-disposal of GTCC LLW and certain portions of DOE SCW is technically feasible.

Further analysis of issues in the report indicates concerns regarding regulatory responsibilities and program strategy for co-disposal of GTCC LLW with DOE SCW. Two points bring this to light: (a) A dilemma could arise in the current division of regulatory responsibilities between the NRC and DOE (i.e., current requirement for disposal of GTCC LLW in an NRClicensed facility). DOE SCW is currently not subject to this licensing requirement, (b) Currently, a DOE complex-wide comprehensive strategy does not exist for managing and disposing of SCW. Such a strategy will be necessary to the initial planning for co-disposal of GTCC LLW with SCW.

Following are recommendations for continuing research into the benefit and feasibility of integrating the management and disposal of GTCC LLW with DOE SCW.

- Develop and implement DOE complex-wide management plans for managing SCW. Specific plans for management of this waste do not now exist in the DOE system. This development will be necessary before planning for co-disposal. The GTCC LLW program strategy (developed for DOE by the National Low-Level Waste Management Program) could be used as guidance and for a SCW strategy. In addition, a basic strategy for managing SCW at the INEL has been initiated and could be developed on a complex-wide basis.

- Incorporate a complex-wide standard nomenclature for SCW and GTCC LLW, consistent with Federal regulations and DOE orders, to eliminate confusion when referring to and differentiating among SCW, GTCC LLW, and other wastes. Such a nomenclature has been developed at the INEL and could be incorporated complexwide.

- Develop and implement a complex-wide DOE SCW characterization program to characterize potential SCW forms. The program would determine which SCW forms and subcategories have the same characteristics as GTCC LLW. The program could also determine which forms are mixed SCW or GTCC LLW (as defined by Resource Conservation and Recovery Act requirements).

- Continue to identify and study options for integrating the management and disposal of GTCC LLW and SCW. Disposal of these wastes will likely not occur for at least another 20 years. At that time, the regulatory framework may be more favorable for co-disposal of these wastes. If not, then DOE should consider recommending changes to applicable laws and regulations.

Combining the management and disposal of these two waste types will increase safety and efficiency while decreasing the cost and duplication of effort. 


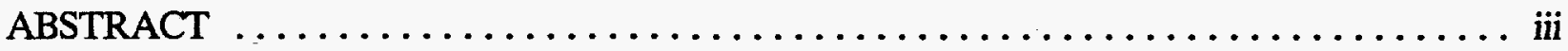

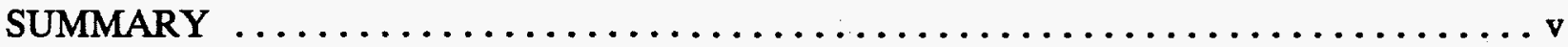

ACRONYMS $\ldots \ldots \ldots \ldots \ldots \ldots \ldots \ldots \ldots \ldots \ldots \ldots \ldots \ldots \ldots \ldots \ldots \ldots \ldots \ldots \ldots \ldots$

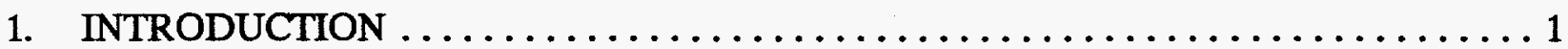

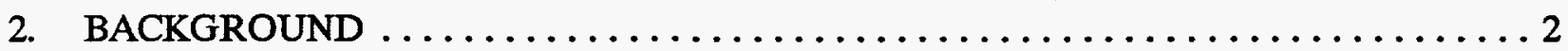

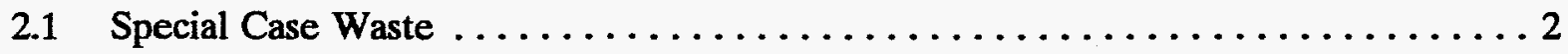

2.1.1 Current Status: SCW $\ldots \ldots \ldots \ldots \ldots \ldots \ldots \ldots \ldots \ldots \ldots$

2.2 Greater-Than-Class C Low-Level Radioactive Waste $\ldots \ldots \ldots \ldots \ldots \ldots \ldots$

2.2.1 Current Status: GTCC LLW $\ldots \ldots \ldots \ldots \ldots \ldots \ldots \ldots \ldots \ldots$

2.3 Historical Background on Laws and Regulation $\ldots \ldots \ldots \ldots \ldots \ldots \ldots$

3. CHARACTERISTICS AND VOLUMES OF SCW COMPARED TO GTCC LLW ... 11

3.1 Characteristics of GTCC LLW Compared to SCW $\ldots \ldots \ldots \ldots \ldots \ldots \ldots$

3.2 Volumes of SCW Compared to GTCC LLW ................. 11

4. REGULATORY CONSIDERATIONS FOR CO-DISPOSAL OF GTCC LLW

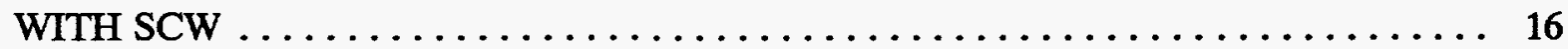

4.1 Examination of Certain Laws and Regulations $\ldots \ldots \ldots \ldots \ldots \ldots \ldots \ldots$

4.1.1 NEPA (Public Law 91-190) $\ldots \ldots \ldots \ldots \ldots \ldots \ldots \ldots \ldots \ldots \ldots \ldots$

4.1.2 Energy Reorganization Act (Public Law 93-438) ............. 17

4.1.3 NWPA (Public Law 97-425) $\ldots \ldots \ldots \ldots \ldots \ldots \ldots \ldots \ldots \ldots \ldots \ldots$

4.1.4 LLRWPAA (Public Law 99-240) $\ldots \ldots \ldots \ldots \ldots \ldots \ldots \ldots \ldots \ldots$

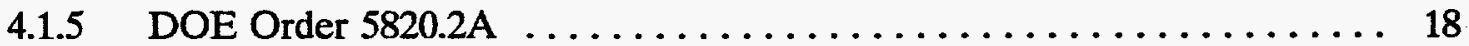

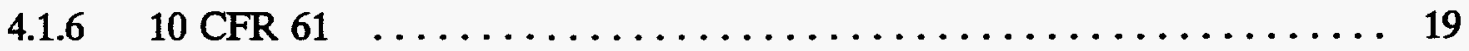

4.1.7 NRC Draft Branch Technical Position, Concentration Averaging and Encapsulation .......................... 19

4.2 Implications of, and Possible Solutions to, NRC Licensing Requirements for the Co-disposal of GTCC LLW with SCW $\ldots \ldots \ldots \ldots \ldots \ldots \ldots \ldots \ldots$

5. TECHNICAL FEASIBILITY OF CO-DISPOSAL OF GTCC LLW WITH SCW $\ldots \ldots 21$ 
5.1 Potential Disposal Systems for GTCC LLW and DOE SCW

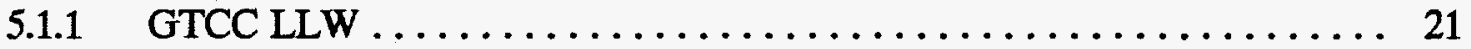

5.1 .2 DOE SCW $\ldots \ldots \ldots \ldots \ldots \ldots \ldots \ldots \ldots \ldots \ldots \ldots \ldots \ldots \ldots \ldots \ldots \ldots \ldots \ldots, 22$

5.2 Disposal Systems Applicable for the Co-disposal of GTCC LLW with DOE SCW $\ldots \ldots \ldots \ldots \ldots \ldots \ldots \ldots \ldots \ldots \ldots \ldots \ldots \ldots \ldots \ldots \ldots \ldots \ldots \ldots, 23$

6. ECONOMIC CONSIDERATIONS FOR CO-DISPOSAL OF GTCC LLW

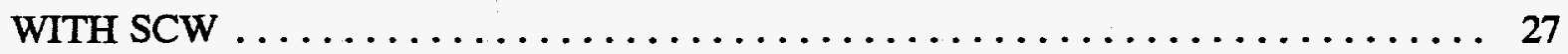

6.1 Waste Characteristics and Waste Volumes $\ldots \ldots \ldots \ldots \ldots \ldots \ldots \ldots \ldots . \ldots \ldots$

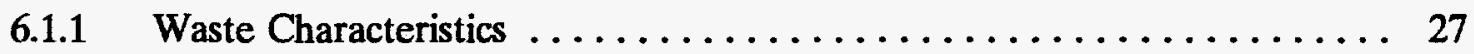

6.1 .2 Waste Volumes $\ldots \ldots \ldots \ldots \ldots \ldots \ldots \ldots \ldots \ldots \ldots \ldots \ldots \ldots$

6.2 Disposal Costs ................................. 27

7. ADVANTAGES AND DISADVANTAGES OF CO-DISPOSING OF GTCC

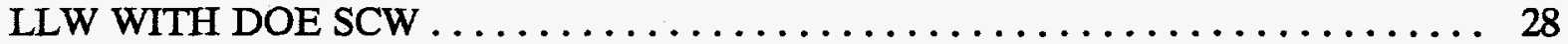

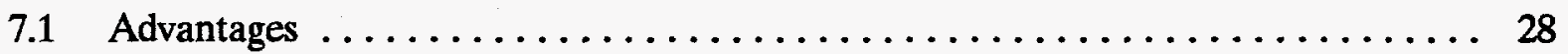

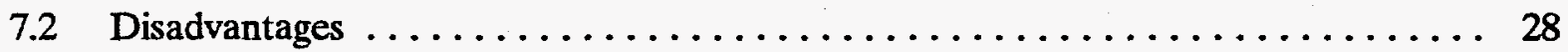

8. CONCLUSIONS $\ldots \ldots \ldots \ldots \ldots \ldots \ldots \ldots \ldots \ldots \ldots \ldots \ldots \ldots \ldots \ldots \ldots \ldots \ldots \ldots \ldots$

9. RECOMMENDATIONS $\ldots \ldots \ldots \ldots \ldots \ldots \ldots \ldots \ldots \ldots \ldots \ldots \ldots \ldots \ldots \ldots \ldots \ldots \ldots$

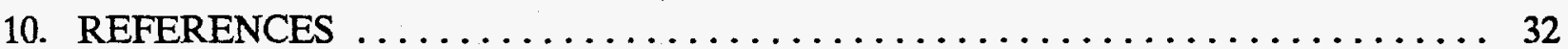

\section{FIGURES}

1. Comparison in radioactive waste classification of DOE and commercial waste $\ldots \ldots \ldots 12$

\section{TABLES}

1. NRC limits for Class $\mathrm{C}$ Low-Level Radioactive Waste $\ldots \ldots \ldots \ldots \ldots \ldots \ldots \ldots$

2. Base-case packaged volumes $\left(\mathrm{m}^{3}\right)$ of GTCC LLW through the year $2035 \ldots \ldots \ldots \ldots$

3. Total volume $\left(\mathrm{m}^{3}\right)$ for each $\mathrm{SCW}$ subcategory $\ldots \ldots \ldots \ldots \ldots \ldots \ldots \ldots \ldots \ldots$

4. Estimated SCW equivalent to GTCC LLW in storage $\ldots \ldots \ldots \ldots \ldots \ldots \ldots \ldots$ 
5. Matrix that compares disposal systems and suggests disposal concepts/options for GTCC LLW and SCW 


\section{ACRONYMS}

\begin{tabular}{|c|c|}
\hline AEA & Atomic Energy Act \\
\hline $\mathrm{AEC}$ & Atomic Energy Commission \\
\hline DOE & U.S. Department of Energy \\
\hline DOE-HQ & U.S. Department of Energy Headquarters \\
\hline DOL & U.S. Department of Labor \\
\hline DOT & U.S. Department of Transportation \\
\hline EIS & environmental impact statement \\
\hline EPA & Environmental Protection Agency \\
\hline ER & Energy Research \\
\hline ERDA & Energy Research and Development Administration \\
\hline GCD & greater confinement disposal \\
\hline GTCC & greater-than-Class $\mathrm{C}$ \\
\hline GTCC LLW & greater-than-Class $\mathrm{C}$ low-level radioactive waste \\
\hline HLW & high-level radioactive waste \\
\hline INEL & Idaho National Engineering Laboratory \\
\hline LLRWPAA & $\begin{array}{l}\text { Low-Level Radioactive Waste Policy Amendments Act of } \\
1985\end{array}$ \\
\hline LLW & low-level radioactive waste \\
\hline NCDP & Noncertified Defense Programs \\
\hline NE & Nuclear Energy \\
\hline NEPA & National Environmental Policy Act \\
\hline NLLWMP & National Low-Level Waste Management Program \\
\hline NONDP & Non-Defense Programs \\
\hline
\end{tabular}


U.S. Nuclear Regulatory Commission

NTS

Nevada Test Site

NWPA

Nuclear Waste Policy Act

OCRWM

Office of Civilian Radioactive Waste Management

ORNL

Oak Ridge National Laboratory

PNL

Pacific Northwest Laboratory

RCRA

Resource Conservation and Recovery Act

SCW

special case waste

SPAR LLW

Special Performance Assessment Required Low-Level

Radioactive Waste

SSDP LLW

Site-Specific Disposal Problem Low-Level Radioactive Waste

TRU

transuranic

WAC

waste acceptance criteria

WIPP

Waste Isolation Pilot Plant

WTIP

waste type implementation plan 


\section{Potential Co-disposal of Greater-Than-Class C Low-Level Radioactive Waste with Department of Energy Special Case Waste}

\section{INTRODUCTION}

This document evaluates the feasibility of co-disposal of greater-than-Class $\mathrm{C}$ low-level radioactive waste (GTCC LLW) with U.S. Department of Energy (DOE) special case waste (SCW).

The document will begin with a discussion on the background and current approach for managing these wastes. Data collected in recent studies on the characterization and management of GTCC LLW and SCW nationally and at the Idaho National Engineering Laboratory (INEL) will form the basis for this report. Key issues to be discussed include

- Waste Characteristics and Volumes of SCW Compared to GTCC LLW: Discusses characteristics and similarities of SCW and GTCC LLW as well as giving estimated volumes of these waste types.

- Regulatory Considerations for Co-disposal of GTCC LLW with SCW: Discusses existing regulatory framework and guidance and how it would affect co-disposal of GTCC LLW with SCW (this will include the issue of concentration averaging).

- Technical Feasibility for Co-disposal of GTCC LLW with SCW: Discusses and compares current disposal technology for GTCC LLW and SCW. Identifies and discusses concepts and options that may be applicable to the co-disposal of these wastes.

- Economic Considerations for Potential Co-disposal of GTCC LLW with SCW: Discusses the economics of co-disposal of GTCC LLW with DOE SCW.

With information from the above issues, advantages and disadvantages of co-disposing GTCC LLW with SCW are identified and examined, and recommendations and conclusions are given.

This document is written solely for the purpose of identifying, researching, and analyzing different issues surrounding the disposal of GTCC LLW with DOE SCW. The GTCC LLW Management Program, itself, does not have a position on political or regulatory issues concerning such operations.

Numerical estimates used in this report are from recent studies on GTCC LLW and SCW. These estimates are conservative and are used solely to compare different data on GTCC LLW and DOE SCW, including volumes, and, under certain assumptions, estimated disposal costs. 


\section{BACKGROUND}

The background information given in this section is essential to understanding issues involved in the potential co-disposal of GTCC LLW with SCW. The pertinent information is presented in three subsections:

- Special Case Waste

- Greater-Than-Class C Low-Level Radioactive Waste

- Historical background on laws and regulations.

\subsection{Special Case Waste}

When DOE issued Order 5820.2A, "Radioactive Waste Management," in September 1988, it enacted a comprehensive plan for managing its radioactive wastes. The order addresses three major categories of radioactive waste: high-level radioactive waste (HLW), transuranic waste (TRU), and low-level radioactive waste (LLW). However, not all DOE wastes fit the criteria for these three major radioactive waste types. Some wastes may have characteristics of more than one of the major waste types, which can prevent their management as typical HLW, TRU, or LLW. Such wastes can pose problems to generators, handlers, and disposal facility operators. DOE has termed these wastes SCW. Currently, the disposal alternatives for SCW are limited, if they exist at all. For example, the waste may not pass established waste acceptance criteria (WAC) or may not be sufficiently characterized to determine disposal requirements. Such wastes will require special management and disposal schemes.

Efforts have begun to characterize DOE's SCW on a national basis and at several DOE facilities. In May 1990, the Radioactive Waste Technical Support Program at the INEL prepared the draft report, Department of Energy Special Case Radioactive Waste Inventory and Characterization Data Report, and associated supplemental data reports. ${ }^{\mathrm{a}}$ That report presented the results of a DOE complex-wide survey on SCW. SCW data summaries were presented complex-wide for each DOE operations office, giving the inventory, approximate volumes, and radionuclide activities (in curies) for SCW. The study also determined that SCW includes such a wide variety of forms and isotopic mixtures that it must be subdivided into several subcategories. The report proposed dividing SCW into eight subcategories.

In the summer of 1993, a new waste management program was implemented through EG\&G Idaho, Inc., at the INEL. A waste type implementation plan (WTIP) was issued in September 1993. This report, titled Special Case Waste and Greater-Than-Class C Low-Level Radioactive Waste Type Implementation Plan, ${ }^{1}$ provided a method for implementing the INEL SCW and GTCC LLW management strategy contained in the DOE report Waste Management Division Strategic Plan. ${ }^{2}$ All of the elements necessary for cradle-to-grave management were included in the WTIP.

a. Information taken from unpublished documentation of work in progress. 
In September and October 1993, a series report containing three volumes, titled DOE Special Case Waste and DOE-Held Greater-Than-Class C Low-Level Radioactive Waste at the INEL, ${ }^{3}$ was issued in concert with the SCW and GTCC LLW WTIP at the INEL. In Volumes 1 and 2 of this report, six revised SCW subcategories were proposed (updated from the original eight subcategories; see footnote $a)^{b}$ and based primarily on disposal requirements. These SCW subcategories were defined as:

- $\quad$ Noncertifiable defense TRU. Noncertifiable defense TRU waste is TRU waste that does not meet the Waste Isolation Pilot Plant (WIPP) WAC. There is no disposal alternative for wastes that cannot be accepted at WIPP.

- Nondefense TRU. Nondefense TRU waste is DOE-titled waste generated by Energy Research Programs, Nuclear Energy (NE) Programs, or a Nuclear Regulatory Commission (NRC)-licensee and having TRU radionuclide concentrations $>100 \mathrm{nCi} / \mathrm{g}$. WIPP will dispose of only TRU waste generated by DOE Defense Programs. Therefore, there is presently no disposal alternative for nondefense TRU wastes.

- Special Performance Assessment Required Low-Level Radioactive Waste (SPAR LLW). SPAR LLW is DOE-titled waste that exceeds the limits specified in Tables 1 and 2 of 10 CFR 61.55 for certain radionuclides (see Table 1 in this report). The exception to this would be SCW that exceeds 10 CFR 61 limits because it has TRU radionuclide concentrations $>100 \mathrm{nCi} / \mathrm{g}$ (i.e., nondefense TRU). SPAR LLW is not generally acceptable for disposal in current near-surface land disposal facilities.

- $\quad$ Site-Specific Disposal Problem Low-Level Radioactive Waste (SSDP LLW). SSDP LLW is radioactive waste that has radionuclide concentrations below the 10 CFR 61.55 Tables 1 and 2 limits, but does not meet the site-specific disposal performance requirements and WAC.

- Fuel and fuel debris. Fuel and fuel debris are elements similar to those destined for the HLW repository. These components were originally used in research and development applications. Consequently, the configurations are unlike normal commercial fuel elements; this may render them unacceptable to the HLW repository WAC.

- Uncharacterized potential SCW. The uncharacterized potential SCW subcategory includes containers of waste with unknown contents. The waste is believed to contain SPAR LLW or TRU waste constituents.

A number of efforts have been initiated at the Hanford site, specifically by Westinghouse Hanford and Pacific Northwest Laboratory. These tasks deal with the identification, characterization, relocation, and storage options for SCW at the Hanford site.

b. In the work in progress referred to in footnote a, the SCW subcategories cover the whole spectrum of radioactive problem materials and waste within the DOE complex. In Reference 3, the revised SCW subcategories just cover radioactive waste, not materials such as excess nuclear materials and sealed sources. When these materials are declared waste, they can then be placed in the most applicable revised SCW subcategory. 
Table 1. NRC limits for Class C Low-Level Radioactive Waste.

Long-lived radionuclides

(Table 1 in 10 CFR 61.55)

\begin{tabular}{|c|c|}
\hline Nuclide (half-life) & $\begin{array}{l}\text { Concentration } \\
\left(\text { curies } / \mathrm{m}^{3}\right)\end{array}$ \\
\hline Carbon-14 (5,730 yr) & 8 \\
\hline Carbon-14 in activated metal $(5,730 \mathrm{yr})$ & 80 \\
\hline Nickel-59 in activated metal $(75,000 \mathrm{yr})$ & 220 \\
\hline Niobium- 94 in activated metal $(20,000 \mathrm{yr})$ & 0.2 \\
\hline Technetium-99 (214,000 yr) & 3 \\
\hline Iodine-129 $(16,000,000 \mathrm{yr})$ & 0.08 \\
\hline & (nanocuries/gram) \\
\hline Alpha-emitting transuranics (greater than $5 \mathrm{yr}$ ) & 100 \\
\hline Plutonium-241 (14 yr) & 3,500 \\
\hline Curium-242 (162.8 days) & 20,000 \\
\hline \multicolumn{2}{|c|}{$\begin{array}{l}\text { Short-lived radionuclides } \\
\text { (Table } 2 \text { in } 10 \text { CFR 61.55) }\end{array}$} \\
\hline Nuclide (half-life) & $\begin{array}{l}\text { Concentration } \\
\text { (curies } / \mathrm{m}^{3} \text { ) }\end{array}$ \\
\hline Nickel-63 (100 yr) & 700 \\
\hline Nickel-63 in activated metal (100 yr) & 7,700 \\
\hline Strontium-90 (29 yr) & 7,000 \\
\hline Cesium-137 (30 yr) & 4,600 \\
\hline \multicolumn{2}{|c|}{$\begin{array}{l}\text { a. Limits are for single radionuclides. For mixtures of radionuclides, limits are obtained by a sum-of- } \\
\text { fractions rule separately for long-lived and short-lived radionuclides. The sum of fractions for either } \\
\text { short- or long-lived radionuclides is determined by dividing each nuclide's concentration by its Class } \mathrm{C} \\
\text { limit and adding the resulting values. If the sum exceeds } 1 \text { for either short- or long-lived radionuclides, } \\
\text { the waste is greater-than-Class C. }\end{array}$} \\
\hline
\end{tabular}




\subsubsection{Current Status: SCW}

A DOE complex-wide comprehensive strategy does not exist for managing SCW. As noted, initial efforts to characterize DOE's SCW have begun at the INEL and the Hanford site. Although this is a start, much more complex-wide guidance will be required.

The initial inventory and characterization study on SCW (see footnote a) indicates that approximately $80 \%$ of the total volume $\left(993,000 \mathrm{~m}^{3}\right)$ of all SCW is uncharacterized waste from the 177 underground storage tanks and old reactors at the Hanford site. Volumes 1 and 2 of Reference 3 indicate that much of SCW at the INEL is also uncharacterized. Hanford possesses over $90 \%$ of the total volume of noncertifiable defense TRU waste and SPAR LLW. Hanford also possesses over $60 \%$ of the total volume of nondefense TRU waste. The Savannah River Office possesses more than $85 \%$ of the SSDP LLW.

At the INEL, SCW is stored at facilities throughout the site, most at the site of generation. Much of this waste is defined as uncharacterized potential SCW. This leads to erroneous waste volume projections, making future management planning very difficult. An important reason why this waste is uncharacterized is cost. Generally, a waste is characterized only when disposal is imminent. This same situation prevails throughout the DOE complex.

All of this waste must be managed as SCW until more detailed characterization capabilities are available. (More detailed characterization may define some of this waste as DOE waste types such as HLW, TRU or LLW.) Relatively speaking, as compared to the defined DOE waste types, only a small quantity of SCW exists in the DOE complex. This results in a low priority for managing this waste, making it difficult to obtain funding for the required activities. Detailed characterization (physical and chemical) of SCW will take some time, resulting in the need for long-term storage.

\subsection{Greater-Than-Class C Low-Level Radioactive Waste}

GTCC LLW is commercial radioactive waste, generated by NRC and Agreement State licensees, that exceeds the Class C limits defined in 10 CFR 61. The 10 CFR 61 codifies disposal requirements for three classes of LLW considered generally suitable for near-surface disposal. They are $\mathrm{A}, \mathrm{B}$, and $\mathrm{C}$, with Class $\mathrm{C}$ waste requiring the most rigorous disposal specifications. Waste with concentrations above Class $\mathrm{C}$ limits for certain short- and long-lived radionuclides is referred to as GTCC LLW (see Table 1). ${ }^{c}$ Under Public Law 99-240, "Low-Level Radioactive Waste Policy Amendments Act of 1985" (LLRWPAA), the Federal Government (i.e., DOE) is responsible for the safe disposal of GTCC LLW. GTCC LLW accepted in accordance with the LLRWPAA must be disposed of in a facility licensed by the NRC. The NRC further requires that GTCC LLW be disposed of in a geologic repository, unless DOE proposes an alternative that can be shown to adequately protect the public health, safety, and the environment and that is approved by the NRC.

c. Commercially generated GTCC LLW is defined by the NRC as having a radionuclide concentration that exceeds the concentration values in NRC Tables 1 or 2 of 10 CFR 61.55. These NRC tables are provided in Table 1 of this report. 
The term GTCC LLW is often incorrectly applied to DOE-owned or -generated waste. DOE-owned or -generated waste that has concentrations above Class $\mathrm{C}$ limits and that does not fall into defined DOE waste categories (i.e., not HLW, TRU, or LLW) is included within certain subcategories of DOE SCW.

In contrast to SCW, a DOE comprehensive strategy does exist for managing GTCC LLW. The GTCC LLW Management Program, part of the National Low-Level Waste Management Program (NLLWMP), was initiated by DOE to plan and develop strategies for managing and disposing of GTCC LLW. As reflected in the document Reassessment of the Greater-ThanClass-C Low-Level Radioactive Waste Program, ${ }^{4}$ DOE's GTCC LLW Management Program contemplates a strategy of:

- Near-term (or emergency) storage of a limited quantity of GTCC LLW (primarily sealed radiation sources) to address potential threats to public health and safety

- Simultaneous planning of a dedicated storage system that would allow broader acceptance of GTCC LLW, on an "as needed" basis, before disposal capacity is available

- Disposal in accordance with 10 CFR 61 in a deep geologic environment, unless other types of disposal are approved by NRC.

Storage and disposal for GTCC LLW, depending on assumptions, could be at one centralized facility or in multiple facilities. The timetable for establishing disposal capabilities is approximately the year 2015 .

Efforts are in process to characterize DOE-held potential GTCC LLW both on a national basis and at the INEL. Just as for SCW, planning for storage or disposal of GTCC LLW requires detailed characterization of that waste to estimate volumes, radionuclide activities, and waste forms. The NLLWMP, in working towards fulfilling this requirement, prepared and issued the report Greater-Than-Class C Low-Level Radioactive Waste Characterization: Estimated Volumes, Radionuclide Activities, and Other Characteristics, in August 1991. This report was revised in 1994..$^{5}$ Data within this report were obtained from existing literature, disposal records, and solicited responses from waste generators and were used to estimate the characteristics and project the volumes and radionuclide activities to the year 2035. (Only the base case data from Reference 5 are used in this report.) These data were placed into four categories, as defined by generator type:

1. Nuclear Utility Waste. Nuclear utility waste comes from commercial nuclear power reactors throughout the United States. A large part of this waste is activated metals or comes from nonfuel-bearing hardware components. (This waste is similar to the SCW subcategory nondefense TRU.) The remainder is operations generated waste.

2. DOE-Held GTCC LLW. LLW exceeding Class $\mathrm{C}$ limits that has already been accepted by DOE under contract arrangements with licensees or in response to health and safety concerns. A large part of this waste comes from programs sponsored by the government to develop nuclear fuel cycles, equipment design, etc. [Interpretation of a 
Department of Energy Idaho Operations Office legal opinion regarding the disposal requirements for certain wastes (potential GTCC LLW) presently stored at DOE facilities has determined that this waste should be classified as SCW. This legal opinion is currently at the Department of Energy Headquarters (DOE-HQ) for review and concurrence.]

3. Other Generator Waste. The Other Generator waste category consists of wastes from small generators such as medical institutions, academic research reactors, and industrial research and development firms. Much uncertainty exists concerning the volumes and activity of this waste. The GTCC LLW Management Program is working on more detailed characterization of this category.

4. Sealed Sources. Sealed sources consist of small capsules, usually stainless steel, that enclose relatively high concentrations of a single nuclide. Sealed sources are used in a wide range of applications, including industrial and medical applications. Sealed sources that exceed Class C limits in 10 CFR 61 and that may not have safe storage, or are abandoned, may be of immediate concern to public health and safety. Immediate storage (near term) may be needed.

Until recently, GTCC LLW has been viewed as a class of waste to be disposed of by one mode of disposal. However, the characteristics of the various waste streams from which this waste type is derived vary significantly and will require different management and disposal methods. For example, wastes within these categories, accounting for radionuclide activity, waste form, and certain disposal restrictions, are similar to certain SCW subcategories discussed above. Initial characterization at the INEL has shown that most GTCC LLW characteristics will be similar to nondefense TRU or SPAR LLW SCW subcategories.

\subsubsection{Current Status: GĩCC LLW - :}

As noted, GTCC LLW strategy has been developed on a national basis. Currently, limited amounts of existing waste that have been identified as GTCC LLW are being stored at different commercial facilities, usually where it was generated. One exception is the DOE-held potential GTCC LLW (candidate SCW) that was accepted by DOE and is being stored at various Federal facilities. Projections for GTCC LLW identified in Reference 5 are given for the years 1993 through 2035 (through 2055 in the case of nuclear utility waste) (see Table 2). It is anticipated that approximately $2,932 \mathrm{~m}^{3}$ of GTCC LLW will be generated by nuclear utilities. Much of the nuclear utility waste has not yet been generated, but will be as a result of decontamination and decommissioning of nuclear utilities.

Approximately $1,000 \mathrm{~m}^{3}$ of the total projected volume $\left(3,250 \mathrm{~m}^{3}\right)$ of GTCC LLW reported in DOE/LLW-114, Revision 0 (1991) are already in the possession of DOE and stored at DOE facilities. This waste is known as DOE-Held potential GTCC LLW. Reference 5 (DOE/LLW-114, Revision 1) states that DOE-Held potential GTCC LLW will be classified as DOE SCW. The volume of this waste reported in Reference 5 is projected to be $0 \mathrm{~m}^{3}$. Future GTCC LLW will be accepted by DOE on a case-by-case basis from generators that are either in the Nuclear Utility, Sealed Sources, or Other Generators category. 
Table 2. Base-case packaged volumes $\left(\mathrm{m}^{3}\right)$ of GTCC LLW through the year 2035.

\begin{tabular}{lc}
\multicolumn{1}{c}{ GTCC LLW category } & $\begin{array}{c}\text { Total estimated volume } \\
\left(\mathrm{m}^{3}\right)\end{array}$ \\
\hline Nuclear Utility & 2,932 \\
DOE-Held & 0 \\
Other Generators & 465 \\
Sealed Sources & 242 \\
Total & $3,638.00$
\end{tabular}

a. Excerpt from Reference 5 .

Since these wastes will come from one of the other categories described in this report, the total inventory of GTCC LLW will not be increased if wastes are classified as DOE-Held in the future. This category will be left open for possible future GTCC LLW that could be accepted by DOE.

Approximately $465 \mathrm{~m}^{3}$ of the total projected volume of GTCC LLW is in the Other Generators category. Storage may be limited for GTCC LLW in this category, and it may require near-term handling.

The total projected volume of sealed sources packaged for a storage scenario is estimated to be approximately $242 \mathrm{~m}^{3}$. It has been estimated in the draft report Characterization of GreaterThan-Class C Low-Level Radioactive Waste, Volume 1: Sealed Sources Held by Specific Licensee, that there are nearly 88,000 sealed sources that could become GTCC LLW. ${ }^{6}$ However, many of these sources can be recycled or reused, resulting in nuclear materials rather than nuclear wastes. Lost or abandoned sealed sources are an immediate concern, and the U.S. Nuclear Regulatory Commission (NRC) will request that DOE provide safe storage for these sources.

The LLRWPAA requires that DOE be responsible for disposal of GTCC LLW in a facility licensed by the NRC. Such a facility will not be available for approximately 20 years. Therefore, GTCC LLW that is accepted by DOE will have to be safely stored until it can be disposed of in an NRC-licensed facility. Pending legislative and regulatory change, long-term storage will be required.

\subsection{Historical Background on Laws and Regulation}

The management of radioactive materials has been subject to laws and regulations for over 40 years. Requirements have evolved as experience has been gained, and programs have changed with the political climate. A review of the historical background will help to understand the current situation.

The Atomic Energy Act (AEA) of 1946 established the Atomic Energy Commission (AEC) and directed it to conduct research and development on peaceful applications of fissionable and 
radioactive materials. The AEA of 1954 emphasized both domestic and international uses of the atom. It also provided for the control of "source material" (uranium and thorium), "special nuclear material" (plutonium and enriched uranium), and "by-product material" (radioactive substances).

The Energy Reorganization Act of 1974 divided the functions of the AEC (the developmental and regulatory), between two agencies, the Energy Research and Development Administration (ERDA) and the NRC. The Energy Organization Act of 1977 replaced ERDA with the current DOE, which also absorbed several other energy-related government programs. DOE provides guidance and regulations for dealing with radioactive material through DOE orders under authority of the AEA and amendments.

The NRC has jurisdiction over construction and operation of commercial reactors. It also licenses and regulates the possession, use, transportation, handling, and disposal of commercial radioactive materials, including wastes.

The purpose of the National Environmental Policy Act of 1969 (NEPA) is "to prevent or eliminate damage to the environment and biosphere and stimulate the health and welfare of man." NEPA requires every Federal action that may significantly affect the environment to be accompanied by an environmental impact statement (EIS). An EIS is a document that describes alternatives, social and economic effects, public comments and agency answers, and hearing board reports.

The U.S. Environmental Protection Agency (EPA) was created by presidential order (Reorganization Plan No.3, 1970), with responsibility for air and water standards, limits on pollutants, and control of radioactivity. The Reorganization Plan transferred to EPA certain radiation authorities from the AEA of 1954, as amended. One authority was that of making recommendations to the President concerning guidance to appropriate Federal regulatory agencies for the formulation of radiation standards. A second radiation authority given to EPA was that it establish generally applicable environmental standards to protect the environment from radiation and radioactive materials. The EPA was not authorized to set standards for radiation contained inside nuclear facilities. These standards are established and implemented by DOE and NRC. DOE establishes standards for weapons plants and energy research and development facilities, while the NRC establishes standards for commercial facilities. The EPA provides for public participation through meetings, hearings, and advisory group reviews.

Other involved agencies are the U.S. Department of Transportation (DOT), which provides rules on the shipment of all kinds of radioactive materials; the U.S. Department of Labor (DOL), which provides rules and regulates the safety and welfare of personnel from occupational exposure; and local and State governments, which provide guidance and enforcement on local laws, regulations, and other requirements.

The relationships of the three agencies that most directly affect waste management can be summarized as follows:

- $\quad$ EPA provides radiation protection standards 
- $\quad \mathrm{NRC}$ licenses and regulates commercial waste disposal under EPA limits

- DOE researches and develops, guides and enforces regulation through DOE orders, advises and assists with low-level waste disposal programs, and will operate defense and HLW repositories.

Major legislation in the areas of LLW (the LLRWPAA) and HLW (the Nuclear Waste Policy Act) provides the basis for the nation's programs in waste disposal.

The LLRWPAA was signed into law on January 15, 1986. Under paragraph 3(b)(1) of the LLRWPAA, DOE has responsibility for disposal of the following type of wastes:

(A) LLW owned or generated by DOE

(B) LLW owned or generated by the U.S. Navy as a result of the decommissioning of naval vessels

(C) LLW owned or generated by the Federal Government as a result of any research, development, testing, or production of any nuclear weapon

(D) Any other LLW with concentrations of radionuclides that exceed the limits established by NRC for Class C radioactive waste (GTCC LLW) as defined in 10 CFR 61.55, in effect on January 26, 1983.

Section 3(b)(2) of the LLRWPAA further states that

All radioactive waste designated a Federal responsibility pursuant to subparagraph (b)(1)(D) that results from activities licensed by the NRC under the AEA of 1954, as amended, shall be disposed of in a facility licensed by the NRC that the Commission determines is adequate to protect the public health and safety.

The LLRWPAA then requires that GTCC LLW be disposed of in an NRC-licensed facility.

The Nuclear Waste Policy Act (NWPA) of 1982 assigned DOE the task of assisting utilities in resolving their near-term spent fuel storage problems. The act established a national policy for safely storing, transporting, and disposing of spent nuclear fuel and HLW. Under the act, one of the major responsibilities of DOE is to research, develop, and demonstrate methods for packaging and storing spent fuel and HLW, leading to the resolution of the spent fuel storage problem at the utilities.

Federal regulations are listed in the Code of Federal Regulations, such as 10 CFR 61. The prefix number denotes the subject area. For example, Number 10 has been assigned to Energy, Number 40 to the protection of the Environment, Number 49 to Transportation, and Number 29 to Labor.

Additional information on specific laws and regulations applicable to the co-disposal of GTCC LLW with DOE SCW is found in Section 4 of this report. 


\section{CHARACTERISTICS AND VOLUMES OF SCW COMPARED TO GTCC LLW}

At the INEL, SCW subcategory classifications are based primarily on disposal criteria (e.g., radiological waste management restraints or disposal restrictions). By using these criteria, waste characteristics of certain SCW subcategories and GTCC LLW categories are likely to be similar. This section will compare these similarities and also compare national waste volumes of SCW and GTCC LLW. Discussion includes waste characteristics of SCW compared to GTCC LLW and volumes of SCW compared to GTCC LLW.

\subsection{Characteristics of GTCC LLW Compared to SCW}

Based on similarities between SCW and GTCC LLW, one can assume that a high percentage of wastes from both the DOE and commercial sectors was generated by generally the same type of processes, that is, from processes generally related to nuclear reactors and radiological research and development.

One method of illustrating the similarities between these different waste categories is to compare the waste classification management systems for both commercial and DOE wastes. Figure 1 illustrates that GTCC LLW is similar to the SCW subcategories known as nondefense TRU and SPAR LLW. For example, some commercial potential GTCC LLW that was accepted by DOE and stored at the INEL has basically the same characteristics, radionuclides, and physical forms as certain waste in the DOE TRU waste category (i.e., these wastes were generated through nuclear utility or industrial processes). This potential GTCC LLW has TRU radionuclide concentrations $>100 \mathrm{nCi} / \mathrm{g}$ TRU and, in the DOE system, would therefore be classified as SCW nondefense TRU. Another example would be the SCW subcategory SPAR LLW, which, in the DOE system, consists of waste that exceeds the 10 CFR 61 Tables 1 and 2 limits, with the exception of waste with TRU radionuclide concentrations $>100 \mathrm{nCi} / \mathrm{g}$. Some potential GTCC LLW at the INEL would fit into this subcategory (e.g., the Surry 2 and Turkey Point 3 nuclear fuel assembly skeletons). This would be waste that exceeds Class $\mathrm{C}$ limits but is $<100 \mathrm{nCi} / \mathrm{g}$ TRU.

\subsection{Volumes of SCW Compared to GTCC LLW}

Using data taken from the document referred to in footnote a and from Reference 3, Table 3 gives estimated current total volumes for each SCW subcategory and the DOE facility where the waste is being stored. Also, the table gives a DOE complex-wide estimated total volume of SCW. The data in this table are based on the revised subcategories developed at the INEL.

The data in Table 3 indicate that approximately $993,044 \mathrm{~m}^{3}$ of DOE SCW exist complex-wide (potential future SCW would add to this total). A large percentage, approximately $80 \%$, of the total volume of SCW is uncharacterized. When characterized, some of this waste may fall into 


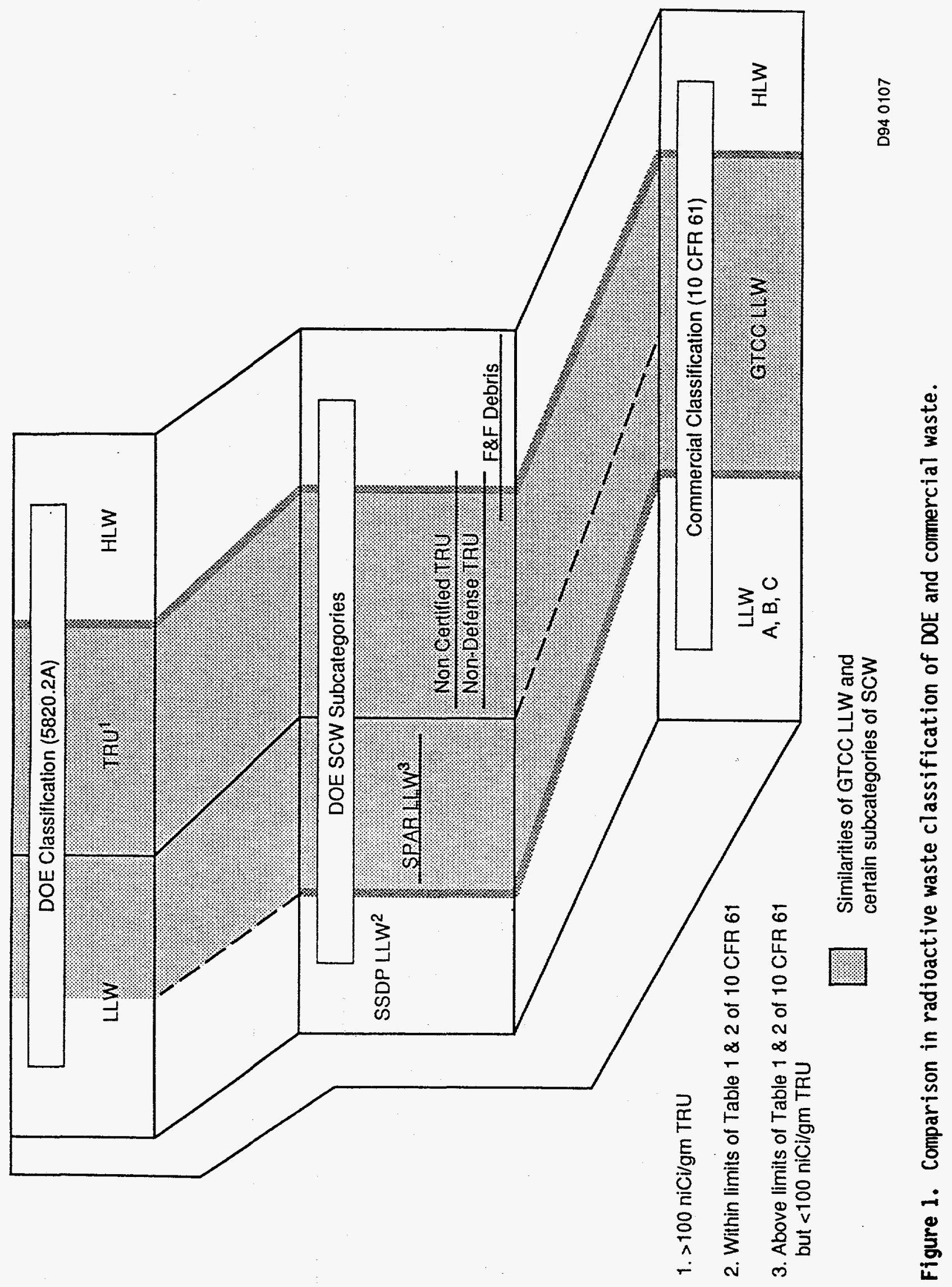


Table 3. Total volume $\left(\mathrm{m}^{3}\right)$ for each SCW subcategory. ${ }^{\mathrm{a}}$

\begin{tabular}{|c|c|c|c|c|c|c|c|}
\hline $\begin{array}{c}\text { Field } \\
\text { office }^{b}\end{array}$ & $\begin{array}{l}\text { NCDPc } \\
\text { TRU }\end{array}$ & $\begin{array}{c}\text { NONDP }^{d} \\
\text { TRU }\end{array}$ & $\begin{array}{l}\text { SPAR } \\
\text { LLW }\end{array}$ & $\begin{array}{l}\text { SSDP } \\
\text { LLW }\end{array}$ & Fuel debris & Uncharacterized & $\begin{array}{c}\text { Total } \\
\text { volume } \\
\left(\mathrm{m}^{3}\right)\end{array}$ \\
\hline AL & 476 & 2.1 & NR & 0.52 & 0.2 & 19.4 & 498 \\
\hline $\mathrm{CH}$ & 6.83 & 28.3 & 47.3 & 4.3 & NR & NR & 87 \\
\hline $\mathrm{ID}$ & 9,030 & 5.2 & 58 & 29,000 & 8,162 & {$[42,023]$} & 46,255 \\
\hline NR & 0.65 & NR & 8.5 & NR & NR & 96.7 & 106 \\
\hline NV & 486 & NR & NR & 727.5 & NR & NR & 1,213 \\
\hline OR & 3.86 & NR & 90.0 & 47.4 & 1.4 & NR & 143 \\
\hline RF & 362 & NR & NR & NR & NR & NR & 362 \\
\hline RL & 32,449 & 547 & 34,042 & 0.07 & 139 & 870,649 & 937,827 \\
\hline SAN & 154 & 3.11 & NR & 0.26 & NR & NR & 157 \\
\hline SR & 1,560 & NR & NR & 4,836 & 0.54 & NR & 6,396 \\
\hline Total & 44,528 & 586 & 34,246 & 34,616 & 8,303 & 870,765 & 993,044 \\
\hline \multicolumn{8}{|c|}{$\begin{array}{l}\text { NOTE: [ ] means number of containers } \\
\text { NR means not reported }\end{array}$} \\
\hline \multicolumn{8}{|c|}{$\begin{array}{l}\text { b. AL - Albuquerque, CH - Chicago, ID - Idaho, NR - Pittsburgh Naval Reactors Office, NV - Nevada, OR - Oak Ridge, RL - } \\
\text { Richland, SAN - San Francisco, SR - Savannah River. }\end{array}$} \\
\hline \multicolumn{8}{|c|}{ c. NCDP - Noncertifiable Defense TRU. } \\
\hline d. NOND & Jon-Defense & RU. & & & & & \\
\hline
\end{tabular}


existing DOE waste categories such as TRU or LLW. However, by using the assumption that $40 \%$ of the uncharacterized SCW subcategory will be SCW equivalent to GTCC LLW, the estimated volume of uncharacterized SCW will be at least $348,306 \mathrm{~m}^{3}$ (see Table 4). ${ }^{\mathrm{d}}$

Data from Reference 5 (depicted in Table 2) indicate that the current and projected total volume of GTCC LLW, base case, is approximately $3,639 \mathrm{~m}^{3}$.

Some uncertainty exists about the portion of each SCW subcategory that is equivalent to GTCC LLW (i.e., has generally the same waste characteristics). However, by using data from the recent characterization study completed at the INEL (see Reference 3), conservative assumptions can be made of the GTCC-LLW-equivalent SCW in each SCW subcategory (see Table 4). These conservative figures show that approximately $411,785 \mathrm{~m}^{3}$ of SCW equivalent to GTCC LLW exist in the DOE system.

The point is to compare the approximate total volume of existing SCW that is similar $\left(411,785 \mathrm{~m}^{3}\right)$ to the approximate total volume of existing and projected GTCC LLW $\left(3,639 \mathrm{~m}^{3}\right)$. The volumes show that the current and projected GTCC LLW estimated total volume is much smaller than the SCW estimated total volume. These figures suggest that, aside from institutional issues, it would be prudent to integrate the management of the GTCC LLW inventory with that of the much larger DOE SCW inventory.

These are conservative estimates. Volumes for GTCC LLW could change significantly in the future depending on changing regulatory requirements, new technology, and classification changes. Examples of these changes could be the use of concentration averaging ${ }^{e}$ or acceptance of nonfuel-bearing components by DOE under the Standard Contract for spent nuclear fuel. Either of these approaches would reduce GTCC LLW volumes to almost nothing.

d. Glenn Bradley, EG\&G Idaho, to Roger Scott, NLLWMP, "GTCC LLW Management," September 9, 1992.

e. Concentration averaging is the practice of placing similar LLW materials together in a container and averaging the radionuclide concentrations of those materials over the volume of the waste containers. For example, when GTCC LLW activated metals are combined with Class A, B, or C metals, the resulting waste package may meet at least Class $\mathrm{C}$, or below, standards for commercial disposal. 
Table 4. Estimated SCW equivalent to GTCC LLW in storage. ${ }^{a}$

\begin{tabular}{|c|c|c|c|}
\hline SCW subcategory & $\begin{array}{c}\text { Total volume } \\
\text { SCW stored } \\
\left(\mathrm{m}^{3}\right)\end{array}$ & $\begin{array}{c}\text { Assumptions for \% SCW equivalent } \\
\text { GTCC LLW }\end{array}$ & $\begin{array}{l}\text { Total volume } \\
\text { SCW equivalent } \\
\text { to GTCC LLW } \\
\text { stored } \\
\left(\mathrm{m}^{3}\right)\end{array}$ \\
\hline NCDP TRU & 44,528 & $\begin{array}{l}\text { Portion of NCDP may be } \\
\text { acceptable at WIPP if processed to } \\
\text { meet WAC; assume } 40 \% \text { eligible }\end{array}$ & 17,811 \\
\hline Non-defense TRU & 586 & $\begin{array}{l}\text { Assume } 100 \% \text { eligible for SCW } \\
\text { equivalent to GTCC LLW }\end{array}$ & 586 \\
\hline SPAR LLW & 34,246 & $\begin{array}{l}\text { Assume } 90 \% \text { eligible for SCW } \\
\text { equivalent to GTCC LLW }\end{array}$ & 30,821 \\
\hline SSDP LLW & 34,616 & $\begin{array}{l}\text { Assume } 40 \% \text { eligible for SCW } \\
\text { equivalent to GTCC LLW }\end{array}$ & 13,846 \\
\hline Fuel debris & 8,303 & $\begin{array}{l}\text { Assume } 0.05 \% \text { eligible for SCW } \\
\text { equivalent to GTCC LLW }\end{array}$ & 415 \\
\hline Uncharacterized & $\underline{870,765}$ & $\begin{array}{l}\text { Assume } 40 \% \text { eligible for SCW } \\
\text { equivalent to GTCC LLW }\end{array}$ & $\underline{348,306}$ \\
\hline Total & 993,044 & & 411,785 \\
\hline
\end{tabular}




\section{REGULATORY CONSIDERATIONS FOR CO-DISPOSAL OF GTCC LLW WITH SCW}

Certain regulatory issues have to be considered in planning for co-disposal of GTCC LLW with DOE SCW. This section examines the existing applicable regulatory framework and guidance and how it will affect these wastes, including

- Examination of certain laws, regulations, and guidance

- Implication of, and possible solutions to, NRC licensing requirements for co-disposal of GTCC LLW with DOE SCW.

\subsection{Examination of Certain Laws and Regulations}

The AEA of 1954, as amended, and related legislation, are implemented through regulations, guidelines, and internal orders from DOE, NRC, and EPA. Other involved agencies include the DOT and DOL (see Section 2.3 of this report).

This subsection will focus on certain laws, regulations, and guidance from DOE, NRC, and EPA that will most directly affect co-disposal of GTCC LLW with DOE SCW. Those that will have a major impact include:

- National Environmental Policy Act of 1969 (Public Law 91-190)

- Energy Reorganization Act of 1974, as amended (Reorganization Act) (Public Law 93-438)

- $\quad$ Nuclear Waste Policy Act of 1982, as amended (Public Law 97-425)

- Low-Level Radioactive Waste Policy Amendments Act of 1985 (Public Law 99-240)

- $\quad$ DOE Order 5820.2A, 1988

- 10 CFR 61, "Licensing Requirements for Land Disposal of Radioactive Wastes," 1983

- $\quad$ NRC Branch Technical Position, "Concentration Averaging and Encapsulation," Draft, September 1993.

\subsubsection{NEPA (Public Law 91-190)}

Before beginning a Federal activity, the proponent is responsible for initiating documentation that complies with NEPA (Public Law 91-190) as amended. The purpose of this NEPA documentation is to evaluate, in the earliest planning stages of the proposal, the impact of the proposed project on the human environment. The NEPA process includes, but is not limited to, conducting an interdisciplinary assessment of potential environmental impacts resulting from the 
project, addressing alternatives for the action, and identifying mitigative measures that may abate environmental impacts.

DOE will have to comply with the NEPA documentation requirements for most activities, including treatment, storage, and disposal of all radioactive waste. This will include activities in the potential co-disposal of GTCC LLW with DOE SCW.

An example of the NEPA process associated with SCW disposal is the DOE Order 5820.2A requirement for a specific performance assessment for disposal of LLW that exceeds the Class $C$ limits defined in 10 CFR 61.

\subsubsection{Energy Reorganization Act (Public Law 93-438)}

The Energy Reorganization Act of 1974 divided the function of the AEC (developmental and regulatory) between two agencies, the ERDA and the NRC (the Energy Organization Act of 1977 replaced ERDA with the current DOE). These two agencies have divided regulatory authority. DOE provides guidance and regulations for DOE radioactive material through DOE orders under authority of the AEA and amendments. The NRC has jurisdiction over construction and operation of commercial nuclear reactors. It also licenses and regulates the possession, use, transportation, handling, and disposal of commercial radioactive materials, including wastes.

The Reorganization Act also gave the NRC specific responsibility to license and regulate four types of DOE facilities:

- $\quad$ Certain breeder reactors

- Certain demonstration nuclear reactors

- Facilities for the receipt and storage of high-level radioactive waste from NRC licensees

- Certain short-term retrievable storage facilities for DOE high-level wastes that are "authorized for the express purpose of long-term storage of high-level radioactive wastes generated by (DOE)."

\subsubsection{NWPA (Public Law 97-425)}

The NWPA provides for the development of repositories for the disposal of high-level radioactive waste and spent nuclear fuel. It also establishes a program for research, development, and demonstration on the disposal of high-level radioactive waste and spent nuclear fuel.

The NWPA gives regulatory authority over these repositories to the NRC by amending the Energy Reorganization Act of 1973. This provided NRC (the Commission) with licensing authority in accordance with the following:

"(3) Any repository for the disposal of high-level radioactive waste resulting from atomic energy defense activities only shall (A) be subject to licensing under section 202 of the 
Energy Reorganization Act of 1973; and (B) comply with all requirements of the Commission for the siting, development, construction, and operation of a repository."

"(c) Applicability to Certain Repositories. - The provisions of this Act shall apply with respect to any repository not used exclusively for the disposal of high-level radioactive waste or spent nuclear fuel resulting from atomic energy defense activities, research and development activities of the Secretary, or both."

This is one of the few areas where the NRC has regulatory authority over a DOE-operated entity.

\subsubsection{LLRWPAA (Public Law 99-240)}

On December 19, 1985, the U.S. Congress passed Public Law 99-240 (LLRWPAA). The LLRWPAA was signed into law on January 15, 1986. This Act and its predecessor, Public Law 96-573, "the Low-Level Radioactive Waste Policy Act of 1980," are the basis for commercial waste management in the United States. Under Paragraph 3(b)(1)(D) of the LLRWPAA, DOE has the responsibility for the safe disposal of commercial LLW with concentrations of radionuclides that exceed the Class C limits (GTCC LLW) established by the NRC in 10 CFR 61. Also, Paragraph 3(b)(2) of the LLRWPAA states that all radioactive waste designated a Federal responsibility pursuant to Subparagraph (b)(1)(D) that results from activities licensed by the NRC or Agreement States shall be disposed of in a facility licensed by the NRC that the commission determines is adequate to protect the public health and safety.

This legislation conveys that GTCC LLW that is, or ultimately will be, accepted by DOE needs to be tracked, segregated from DOE-owned waste, and disposed of in an NRC-licensed disposal facility (i.e., except for a few specific cases, DOE facilities are not regulated by NRC).

\subsubsection{DOE Order 5820.2A}

The purpose of DOE Order 5820.2A is to establish policies, guidelines, and minimum requirements by which the DOE manages its radioactive and mixed waste and contaminated facilities.

The policy of the order states "Radioactive and mixed wastes shall be managed in a manner that assures protection of the health and safety of the public, DOE and contractor employees, and the environment. The generation, treatment, storage, transportation, and/or disposal of radioactive wastes, and the other pollutants or hazardous substances they contain, shall be accomplished in a manner that minimizes the generation of such wastes across program office functions and complies with all applicable Federal, State, and local environmental, safety, and health laws and regulations and DOE requirements."

SCW and GTCC LLW are not discussed in any detail in the order. The only reference is in Chapter III, "Management of Low-Level Waste." Chapter III i. (4) which states "Disposition of waste designated as greater-than-class C, as defined in 10 CFR 61.55, must be handled as special cases. Disposal systems for such waste must be justified by a specific performance assessment 
through the National Environmental Policy Act process and with the concurrence of DP-12 for all DP-1 disposal facilities and of NE-20 for those disposal facilities under the cognizance of NE-1."

DOE Order 5820.2A is being revised; the new revision should be completed in 1995.

\subsubsection{CFR 61}

10 CFR 61, issued in December 1982, established performance objectives for commercial waste disposal sites, a classification system of waste acceptable for shallow-land disposal, and the responsibilities of parties involved in shallow-land disposal of radioactive waste.

The 10 CFR 61 codified disposal requirements considered generally suitable for near-surface disposal of three classes of $\mathrm{LLW}$. They are $\mathrm{A}, \mathrm{B}$, and $\mathrm{C}$, with Class $\mathrm{C}$ waste requiring the most rigorous disposal specifications. Waste with concentrations above Class $\mathrm{C}$ limits for certain shortand long-lived radionuclides was identified as GTCC LLW.

Compliance with 10 CFR 61 is required in the commercial sector. DOE may refer to it as guidance.

\subsubsection{NRC Draft Branch Technical Position, Concentration Averaging and Encapsulation}

The regulation 10 CFR 61 establishes a waste classification system based on the concentration of specific radionuclides contained in the waste. The regulation also states, in 10 CFR 61.55 (a)(8), that, "the concentration of a radionuclide [in waste] may be averaged over the volume of the waste, or weight of the waste if the units [on the values tabulated in the concentration tables] are expressed as nanocuries per gram." NRC prepared a Branch Technical Position for guidance in this matter, the latest drafted in September of 1993.

Concentration averaging is the practice of placing similar LLW materials together in a container and averaging the radionuclide concentrations of those materials. For example, when GTCC LLW activated metals are combined with Class $C$ metals, the resulting packaged waste may meet standards for disposal as commercial Class $\mathrm{C}$ waste.

Storage throughout the commercial sector may be limited for GTCC LLW. Storage for existing GTCC LLW at these facilities (utilities) would be in direct competition with spent nuclear fuel and certain other LLW. To help solve storage problems for these wastes, the commercial sector has been using concentration averaging. If, in the future, States and Compacts adopt concentration averaging policies similar to those practiced today, very little LLW will be classified as GTCC LLW. However, if the States and Compacts are more strict with concentration averaging, then the chance exists for much more LLW being classified as GTCC LLW.

Existing DOE orders and guidance do not mention a DOE complex-wide policy concerning the use of concentration averaging. Individual DOE sites do not recognize the practice of concentration averaging. They depend on the WAC judging each disposal package when it is received at the disposal facility. 


\subsection{Implications of, and Possible Solutions to, NRC Licensing Requirements for the Co-disposal of GTCC LLW with SCW}

The LLRWPAA made the DOE responsible for disposal of commercial GTCC LLW [Section 3(b)(1)(D)] in an NRC-licensed facility [Section 3(b)(2)]. This requirement has some implications in the case for potential co-disposal of GTCC LLW with DOE SCW.

As previously stated, The NRC is authorized to license and regulate DOE-owned facilities only where such authority is expressly given in law (the Reorganization Act and the NWPA). The NRC was given general responsibility for licensing and regulating entities outside DOE that possessed and used certain radioactive materials (i.e., source, byproduct, and special nuclear materials as defined in the AEA).

In the potential co-disposal of commercial GTCC LLW with DOE SCW, there is a dilemma because of the division of regulatory responsibilities between the two agencies. While the NRC does not have express statutory authority under the Reorganization Act to license a DOE facility for disposal of GTCC LLW, the LLRWPAA requires GTCC LLW generated by licensees of the NRC to be disposed of in an NRC-licensed facility. Possible solutions to this dilemma include:

1. Legislation to amend Section 202 of the Reorganization Act to grant the NRC authority to license a DOE-owned disposal facility that accepts GTCC LLW generated by NRC licensees.

2. Legislation to amend Section 3(b)(2) of the LLRWPAA to dissolve the requirement that GTCC LLW must be disposed of in an NRC-licensed disposal facility.

3. Making arrangements to dispose of the waste in a facility owned by an entity that can receive an NRC license.

4. Disposing of the waste in a deep geologic repository developed under the NWPA, currently the only applicable DOE disposal facility for which NRC has some licensing responsibilities and authority. 


\section{TECHNICAL FEASIBILITY OF CO-DISPOSAL OF GTCC LLW WITH SCW}

This section examines the technical feasibility of disposing of GTCC LLW with DOE SCW. It identifies, evaluates, and compares current disposal technology applicable to GTCC LLW and DOE SCW, including

- Potential disposal systems for GTCC LLW and DOE SCW

- Disposal systems applicable for the co-disposal of GTCC LLW with DOE SCW.

\subsection{Potential Disposal Systems for GTCC LLW and DOE SCW}

The DOE has investigated disposal technology for commercial GTCC LLW and, to some extent, DOE SCW. This work has been done through studies and actual demonstrations based on previously defined disposal concepts for LLW, TRU, and HLW.

\subsubsection{GTCC LLW}

The NRC has promulgated regulations requiring GTCC LLW disposal in a geologic repository (10 CFR 61 in 1989). However, DOE can propose an alternative disposal system if it can be shown to adequately protect the public health, safety, and the environment, and is approved by the NRC.

Alternatives for the disposal of GTCC LLW have been identified through a series of studies. The latest study is the report, Technically Feasible Systems for the Disposal of Greater-Than-Class C Low-Level Radioactive Waste. ${ }^{f}$ This report identifies 13 disposal concepts for disposing of GTCC LLW in near-surface (30 meters), intermediate depth (100 meters), and deep geologic facilities (300 meters). These are

- $\quad$ Near surface (30 meters)

- $\quad$ Shallow-land disposal

- $\quad$ Belowground vault

- $\quad$ Modular concrete canisters

- $\quad$ Aboveground vault

- $\quad$ Earth-mounded concrete vault

- Intermediate depth (100 meters)

- $\quad$ Mined cavity; layered placement; high-level-waste type container; canister

- $\quad$ Mined cavity; layered placement; high-integrity-canister

f. Information taken from unpublished documentation of work in progress. 
- $\quad$ Drilled hole; layered placement; high-level-waste type container; canister

- $\quad$ Drilled hole; layered placement; high-integrity; canister

- Deep geologic (300 meters)

- $\quad$ Mined cavity; layered placement; high-level-waste type container; canister

- $\quad$ Mined cavity; layered placement; high-integrity; canister

- $\quad$ Drilled hole; layered placement; high-level-waste type container; canister

- $\quad$ Drilled hole; layered placement; high-integrity; canister

In order to determine the performance of the various disposal concepts, the known characteristics of the GTCC LLW to be disposed of were identified. Performance of these concepts were evaluated in terms of confinement of, and intrusion into, the radioactive wastes. The concepts were evaluated for both arid and humid sites. The study determined and recommended the following technically feasible disposal systems for potential GTCC LLW disposal.

1. The recommended disposal system at an arid site could use either the near-surface modular concrete canister concept, the intermediate-depth drilled hole concept, or the intermediate-depth mined cavity concept. For deep geologic disposal concepts, either drilled holes or mined cavities could be used.

2. The recommended disposal system at a humid site could use only intermediate depth or deep geologic disposal concepts; either drilled holes or mined cavities could be used.

\subsubsection{DOE SCW}

Currently, DOE SCW has limited disposal alternatives. Under DOE CIder 5820.2A, such wastes must be handled as special cases. Disposal systems for SCW that exceeds Class $\mathrm{C}$ limits as defined in 10 CFR 61 must be justified by a specific performance assessment through the NEPA process and with the concurrence of DOE-HQ.

Disposal systems for DOE radioactive waste (for both arid and humid sites) have been studied and demonstrated throughout the DOE Complex. The report Waste Management Facilities Cost Information Report for Greater-Than-Class C and DOE Equivalent Special Case. Waste, ${ }^{7}$ identifies different disposal systems. From research of this and related studies, and actual visits to several DOE sites, GTCC LLW Management Program staff have concluded that disposal concepts for these DOE systems (which would be technically feasible for disposal of SCW) are approximately the same as the concepts identified in the GTCC LLW studies. The following DOE disposal systems, evaluated for both arid and humid sites, would likely be suitable for disposal of SCW:

1. Disposal systems at arid sites would use the near-surface, non-enhanced, shallow-land disposal concept, the intermediate drilled holes concept (greater confinement disposal), and deep geologic disposal concepts (either drilled holes or mined cavities). 
2. Disposal systems at humid sites would use near-surface, enhanced, shallow-land disposal such as aboveground and earth-mounded vaults. Depending on area, deep geologic drilled holes or mined cavities could be used.

\subsection{Disposal Systems Applicable for the Co-disposal of GTCC LLW with DOE SCW}

Table 5 compares subcategories of DOE SCW and GTCC LLW (columns) with the three types of disposal systems (rows) discussed in this report. The table indicates similarities (in shaded areas) between GTCC LLW and SCW in the use of disposal systems and also gives suggested disposal options and concepts for each subcategory.

Analysis of the information acquired through this document indicates that the following disposal systems and concepts, given with examples, could be technically feasible for co-disposal of GTCC LLW and DOE SCW.

\section{- $\quad$ Near surface (30 meters)}

This includes non-enhanced, shallow-land disposal; enhanced, shallow-land disposal such as aboveground, earth-mounded vaults, belowground concrete vaults, and silos fewer than 30 meters deep. Examples of these concepts are shown through ongoing demonstrations held at the Nevada Test Site (NTS) and the Oak Ridge National Laboratory (ORNL).

Non-enhanced, shallow-land disposal, using existing craters from earlier nuclear bomb testing at NTS (arid site): In Area 3 at the NTS, the LLW disposal method uses existing bomb craters created from ground subsidence from the underground weapons testing performed over the years. A cluster of bomb craters is being used for disposal of large containers of LLW. A crater is leveled and prepared to receive waste. The waste is packaged in large containers similar to those used on container ships. The containers are stacked into the crater in layers and overpacked with soil. The craters can contain up to 8 layers of waste. Each waste layer is approximately 8 feet high with 3 feet of overpack. The overpack is fill material from an adjacent crater. When one crater is filled, the adjacent crater is then ready to receive waste. There is a huge potential for further disposal of LLW in this area.

Abovegrade concrete tumulus at the ORNL (humid site): The tumulus disposal unit consists of a $65-\mathrm{ft} \times 105-\mathrm{ft}$, curbed, epoxy-coated, steel-reinforced concrete pad. The pad surface is drained through two lines to a monitoring station. A 30-mil, high-density polyethylene liner isolates the gravel layer under the pad and provides additional monitoring capability through a separate drain line. The tumulus pad can be loaded with contact-handled waste contained in several types of waste containers and placed in rectangular concrete vaults or casks. These vaults or casks can be stacked three or four units high, with the higher activity wastes being stacked in the middle and at the bottom of the pads. The vaults or casks will be covered with a layered earthen mound. Groundwater monitoring wells will be placed around the disposal unit areas. 
Table 5. Matrix that compares disposal systems and suggests disposal concepts/options for GTCC LLW and SCW.

\begin{tabular}{|c|c|c|c|c|c|c|}
\hline \multirow{2}{*}{$\begin{array}{c}\text { Disposal facilities } \\
\text { Waste } \\
\text { type }\end{array}$} & \multirow{2}{*}{$\begin{array}{l}\text { Enhanced shallow- } \\
\text { land burial } \\
(30 \mathrm{~m}) \\
\mathrm{SCW}\end{array}$} & \multirow{2}{*}{$\begin{array}{l}\text { (Below ground } \\
\text { concrete } \\
\text { vaults, etc.) } \\
\text { GTCC LLW }\end{array}$} & \multicolumn{2}{|c|}{$\begin{array}{l}\text { Intermediate depth } \\
\text { (Drilled holes or mined cavities) } \\
\qquad(100 \mathrm{~m})\end{array}$} & \multicolumn{2}{|c|}{$\begin{array}{c}\text { Deep geologic } \\
\text { (Drilled holes or mined cavities) } \\
(300 \mathrm{~m})\end{array}$} \\
\hline & & & SCW & GTCC LLW & SCW & GTCC LLW \\
\hline $\begin{array}{l}\text { SCW non-cert } \\
\text { defense TRU }\end{array}$ & No option & No option & $\begin{array}{l}\text { X res, } \\
\text { GCD, drilled holes. } \\
\text { or mined cavities? }\end{array}$ & No option & 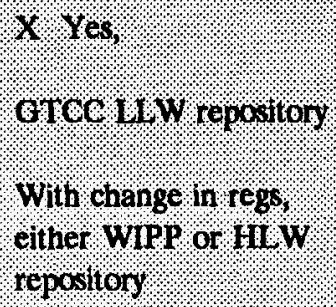 & No option \\
\hline $\begin{array}{l}\text { SCW non-defense } \\
\text { TRU }\end{array}$ & No option & No option & $\begin{array}{l}\text { X Yes, } \\
\text { GCD, drilled holes. } \\
\text { or nined cavities. }\end{array}$ & 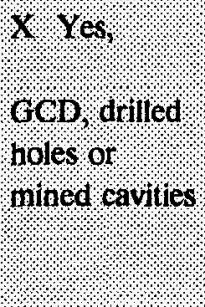 & 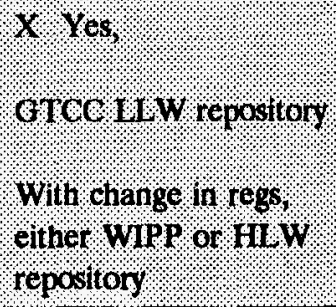 & 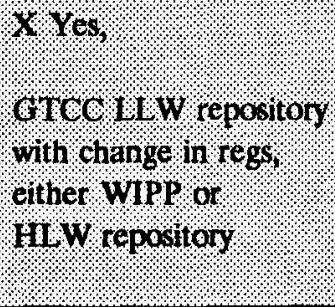 \\
\hline $\begin{array}{l}\text { SCW specific perform } \\
\text { assess required } \\
\text { (SPAR LLW) } \\
<100 \mathrm{nCi} / \mathrm{g} \text { TRU } \\
>10 \mathrm{nCi} / \mathrm{g} \text { TRU }\end{array}$ & $\begin{array}{l}\mathrm{X} \text { Yes, } \\
\text { Engineered } \\
\text { concrete vaults } \\
\text { with waste in high } \\
\text { integrity }: \text { ? } \\
\text { containers }(\mathrm{HIC})\end{array}$ & $\begin{array}{l}\mathrm{X} \text { Yes, } \\
\text { Enginered } \\
\text { concrete } \\
\text { vaults with } \\
\text { waste in HICs. }\end{array}$ & $\begin{array}{l}\mathrm{X} \text { Yes, } \\
\text { GCOD, drilled holes } \\
\text { or mined cavities }\end{array}$ & $\begin{array}{l}\mathrm{X} \text { Yes, } \\
\text { Gcb, driled } \\
\text { holes or } \\
\text { mined cavities? }\end{array}$ & Not necessary & Not necessary \\
\hline $\begin{array}{l}\text { SCW } \\
\text { Site-specific disposal } \\
\text { problem LLW } \\
\text { (SSDP LLW) }\end{array}$ & $\begin{array}{l}\mathrm{X} \text { Yes, } \\
\text { Engineered } \\
\text { concrete vaults } \\
\text { Hibs }\end{array}$ & Not applicable & Not necessary & $\begin{array}{l}\text { Not } \\
\text { applicable }\end{array}$ & Not necessary & Not applicable \\
\hline
\end{tabular}




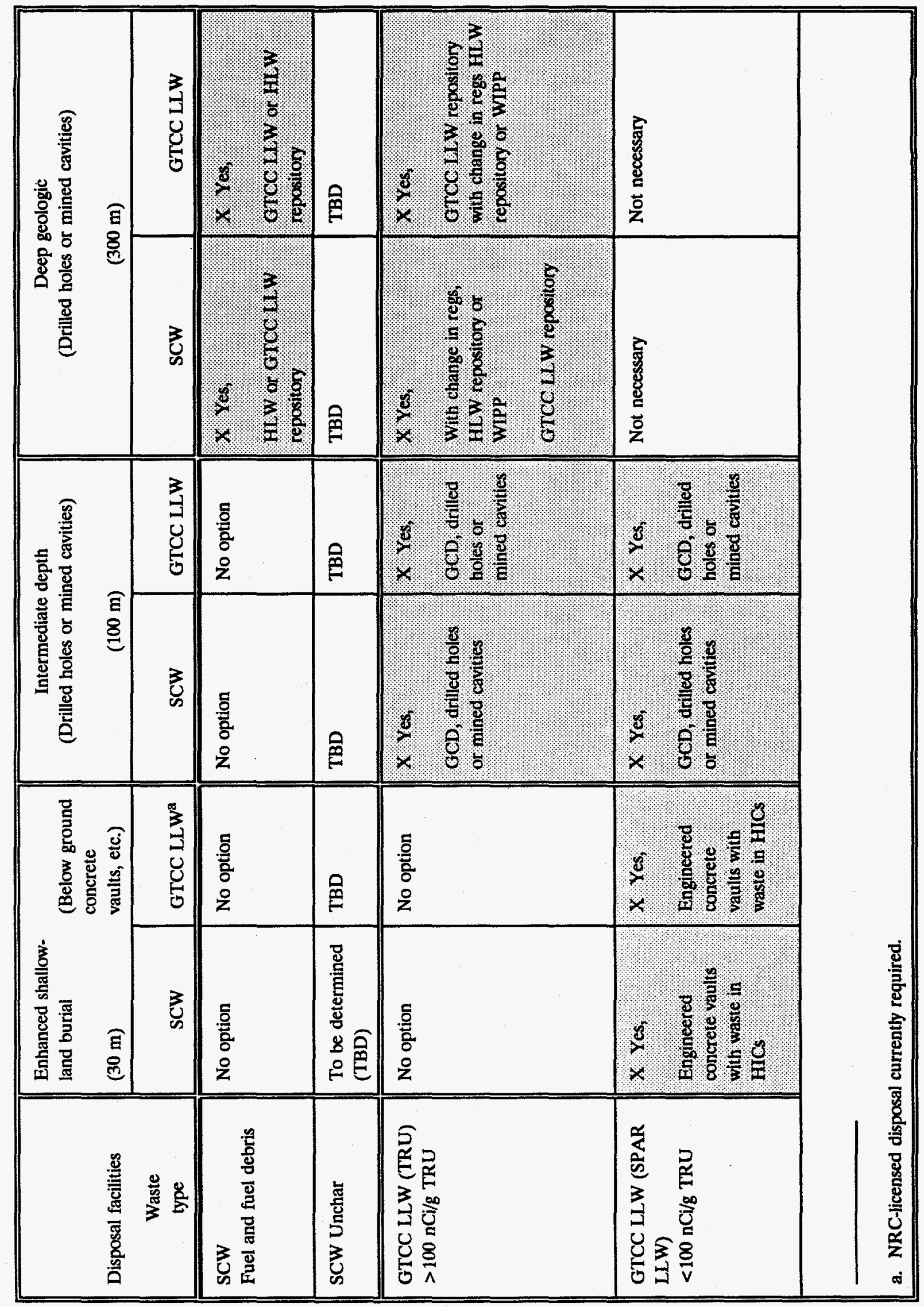


Belowgrade concrete silos at the ORNL (humid site): This concept involves excavating a trench, placing two concentric corrugated metal pipes in the trench, and filling the bottom and annulus with concrete to create a concrete silo. Each silo will include an access pipe to sample the inner silo cavity directly, and an external gravel sump for monitoring and removing water that may infiltrate around the silos. Groundwater monitoring wells will be placed around the disposal unit areas.

- Intermediate depth (100 meters)

This system uses both mined cavities and drilled hole concepts. An example of intermediate depth (the drilled hole concept) is the Greater Confinement Disposal (GCD) holes at the NTS (arid site): In Area 5 at the NTS, GCD tests have been demonstrated since 1981. The tests consist of holes drilled in the ground approximately 10 feet in diameter by 120 feet deep. The GCD holes have no engineered barriers and rely on the natural geology of the area to contain the waste materials. Soil in the area is ideal for limited migration, and groundwater is at approximately the 1200 -foot level. Test holes that have been filled and sealed have had no reported radionuclide activity migrating outside of the hole boundaries. Based on these findings, it is possible that the GCD concept used at NTS could be used as a model for co-disposal of GTCC LLW with SCW. It offers the opportunity to use intermediate-depth disposal methods to place high-activity wastes in a safe configuration. Engineered barriers, such as those used at the ORNL, could be added to provide an extra margin of safety to protect the public health and environment.

- Deep Geologic (300 meters)

This disposal system is the most acceptable, both technically and politically, for disposal of GTCC LLW and SCW. Deep geologic jisposal is generally the accepted disposal concept for radioactive waste above Class $\mathrm{C}$ limits. Vast amounts of information are available on this type of disposal technology; therefore, this report will not go into detail on this concept.

Two examples are the WIPP repository at Carlsbad, New Mexico, and the Planned Yucca Mountain Site repository headquartered at the NTS. Both of these examples are based on the deep geologic, mined cavity concept.

It must be mentioned that, under current DOE requirements, only certain wastes can be disposed of at WIPP (Defense TRU wastes) and Yucca Mountain (spent fuel and HLW). Such requirements are being reinvestigated for future planning of disposal options. 


\section{ECONOMIC CONSIDERATIONS FOR CO-DISPOSAL OF GTCC LLW WITH SCW}

Economics are a major consideration of the feasibility for co-disposal of GTCC LLW with DOE SCW. Discussion in this section includes waste characteristics, waste volumes, and disposal costs.

\subsection{Waste Characteristics and Waste Volumes}

Waste characteristics and waste volumes of GTCC LLW and DOE SCW were discussed in Section 3 of this report. However, the economics of these issues should also be considered.

\subsubsection{Waste Characteristics}

If GTCC LLW and SCW are similar, then the same treatment, storage, and disposal technologies can be applied.

\subsubsection{Waste Volumes}

The base-case projection of all future commercial GTCC LLW generation (through the year 2035 ) is fewer than $4,000 \mathrm{~m}^{3}$. This projected figure is relatively small, less than $1 \%$ of the commercial LLW generated. As a result, it appears that it would be economically prohibitive to site, develop, and operate disposal facilities dedicated solely to GTCC LLW.

It has been roughly estimated that DOE's current waste inventory of SCW that is similar to GTCC LLW is about $400,000 \mathrm{~m}^{3}$. This is a hundred times more than the projected volume of GTCC LLW. These estimates lead to the suggestion that it would be economically feasible, barring regulatory concerns, to integrate the management and disposal of these two waste types.

\subsection{Disposal Costs}

A principal programmatic assumption is that a disposal facility will not be available for GTCC LLW until around 2015. A variety of near-surface, intermediate-depth, and deep geologic disposal technologies have been identified as technically feasible for disposal of GTCC LLW. However, the cost to develop any of these technologies as a stand-alone or dedicated facility solely for disposing of GTCC LLW is estimated at $\$ 300$ to $\$ 500$ million. Given the small projected volume of GTCC LLW $\left(4000 \mathrm{~m}^{3}\right)$, the cost of disposal of GTCC LLW can be expected to be in the range of $\$ 123,599$ per $\mathrm{m}^{3}$ or $\$ 3,500$ per $\mathrm{ft}^{3}$.

Reference 7 develops planning life-cycle cost estimates for treatment, storage, and disposal of GTCC LLW and DOE-equivalent SCW. Assuming that a DOE SCW management strategy is developed and implemented, and GTCC LLW is integrated into the SCW management system, a cost factor can be presented. For example, the cost to develop an intermediate depth disposal facility for the disposal of both GTCC LLW and equivalent SCW (large module) is estimated to be $\$ 43,295$ per $\mathrm{m}^{3}$ or $\$ 1,226$ per $\mathrm{ft}^{3}$. 


\section{ADVANTAGES AND DISADVANTAGES OF CO-DISPOSING OF GTCC LLW WITH DOE SCW}

As a result of the analyses conducted in this document, the following advantages and disadvantages for the potential co-disposal of GTCC LLW with DOE SCW have been identified.

\subsection{Advantages}

- Treatment, storage, and disposal technologies are the same: Analysis of existing characterization and process knowledge suggests that GTCC LLW and certain portions of DOE SCW have very similar waste characteristics and could be treated, stored, and disposed of in the same manner.

- Projected waste volumes support co-disposal: The total estimated volume of DOE SCW $\left(400,000 \mathrm{~m}^{3}\right)$ similar in waste characteristics to GTCC LLW is many times more than the total estimated volume of GTCC LLW (4,000 $\left.\mathrm{m}^{3}\right)$. A stand-alone disposal facility dedicated to GTCC LLW would not be economically feasible. Because of the economy of scale, a co-disposal facility for both of these waste types could be prorated over a larger volume of waste, thereby reducing the cost per unit volume.

- Disposal demonstrations confirm technical feasibility: Studies and actual demonstrations with radioactive waste disposal technology suggest that co-disposal of GTCC LLW and certain portions of DOE SCW is technically feasible.

- Prototype planning documentation exists: Co-disposal and management of GTCC LLW and DOE SCW would be economical by reducing planning (less duplication and paperwork). A DOE SCW/GTCC LLW management program could benefit from planning and documentation that have been developed by the GTCC LLW Management Program (documentation, guidance, startup)

- Approval processes would be coordinated: There would be one set of institutional regulations for each siting attempt (storage, treatment, disposal) instead of two.

\subsection{Disadvantages}

- DOE SCW lacks a complex-wide strategy: Specific plans for management and disposal of DOE SCW presently do not exist in the DOE system. A basic management strategy would be required for DOE SCW in order to plan for disposal of GTCC LLW with DOE SCW.

- DOE and NRC disposal regulations are not compatible: In accordance with the LLRWPAA, waste accepted by DOE specifically for disposal as GTCC LLW must be disposed of in an NRC-licensed facility (or facilities). DOE SCW and DOE disposal facilities are not currently subject to an NRC-licensed disposal requirement. This situation.could result in all of the waste being consigned to NRC-licensed disposal facilities. This may subject DOE activities to external regulatory oversight. 
- DOE and NRC financial responsibility and authority are incompatible: Pending changes in current statutes and regulations, potential co-disposal of GTCC LLW with DOE SCW could result in the necessity to ensure that appropriate financial accounting practices are employed for disposal costs (that is, commercial financial responsibility as compared to DOE financial responsibility.) Also, the two waste types would have to be tracked separately to ensure that GTCC LLW goes to an NRC-licensed disposal facility.

- Reclassification of waste is hindered: Potential co-disposal of GTCC LLW with DOE SCW would reduce the chance that these wastes would ever be reclassified as other wastes (i.e., HLW). The inference is that, if certain categories of GTCC LLW could qualify as HLW [if the Office of Civilian Radioactive Waste Management (OCRWM) would accept nonfuel-bearing components], so can certain subcategories of SCW. This might have major impacts on the plans of OCRWM for disposal of spent fuel. 


\section{CONCLUSIONS}

The DOE is responsible for the safe disposal of GTCC LLW in an NRC-licensed facility, as specified in the LLRWPAA. DOE also generates waste that is technically equivalent to GTCC LLW (known as DOE SCW). Research and analysis of issues presented in this document indicate that it would be technically feasible and economically beneficial to co-dispose of GTCC LLW with DOE SCW. Co-disposal makes good business sense when it is realized that DOE must manage large volumes of waste with characteristics that are similar to GTCC LLW. The total estimated volume of this similar type of DOE SCW $\left(400,000 \mathrm{~m}^{3}\right)$ is many times more than the total estimated volumes of GTCC LLW $\left(4,000 \mathrm{~m}^{3}\right)$.

A dilemma will likely arise in the current division of regulatory responsibilities between the NRC and DOE (i.e., requirement for disposal of GTCC LLW in an NRC-licensed facility). DOE SCW is currently not subject to an NRC-licensed disposal requirement. However, disposal for these wastes will probably not be instigated for another 20 years. At that time, the regulatory framework may be more favorable for co-disposal. If not, then DOE should consider recommending changes to applicable laws and regulations.

It is recommended that research continue into the benefit and feasibility of integrating the management and co-disposal of GTCC LLW and DOE SCW. The common denominator is to have the safest, most economical management and disposal of these waste types. 


\section{RECOMMENDATIONS}

From material that has been compiled and examined in this document, the following recommendations are given

- DOE complex-wide management plans should be developed and implemented for managing DOE SCW. Specific plans for managing this waste presently do not exist in the DOE system. Such plans are a necessity before planning for the potential co-disposal of GTCC LLW with DOE SCW. The GTCC LLW Management Program strategy (developed for DOE by the NLLWMP) could be used as guidance and a basis for SCW strategy. A basic strategy for the management of SCW at the INEL has been initiated and could be developed on a complex-wide basis.

- Standard nomenclature for SCW and GTCC LLW, which is consistent with Federal regulations and DOE orders, should be incorporated complex-wide to eliminate confusion when referring to and differentiating between SCW, GTCC LLW, and other wastes. Such nomenclature has been developed at the INEL and could be incorporated complex-wide.

- A complex-wide DOE SCW characterization program should be developed and implemented to characterize potential SCW forms. The program would determine which SCW forms and subcategories have the same characteristics as GTCC LLW. The program could also determine which forms are mixed SCW or GTCC LLW (as defined by RCRA).

- Options for integrating the management and disposal of GTCC LLW and SCW should continue to be identified and studied. Disposal of these wastes will likely not occur for at least another 20 years. At that time, the regulatory framework may be more favorable for co-disposal of these wastes. If not, then DOE should consider recommending changes to applicable laws and regulations. 


\section{REFERENCES}

1. M. Magleby and J. Roach, Special Case Waste and Greater-Than-Class C Low-Level Radioactive Waste Type Implementation Plan, ER\&WM-PD-93-0303, September 1993.

2. Waste Management Division Strategic Plan, DOE/ID-10429, May 1993.

3. W. Allred and M. Winberg, DOE Special Case Waste and DOE-Held Greater-Than-Class C Low-Level Radioactive Waste at the INEL: Vol 1: Inventory and Characteristics; Vol 2: Management Strategies; Vol 3: Feasibility of Integrating Management and Disposition on a National Basis, EGG-WM-10905, September 1993.

4. Reassessment of the Greater-Than-Class C Low-Level Radioactive Waste Program, EGG-WM-11018, Revision 0, October 1993.

5. Greater-Than-Class C Low-Level Radioactive Waste Characterization: Estimated Volumes, Radionuclide Activities, and Other Characteristics, DOE/LLW-114, Revision 1, September 1994.

6. G. Harris, Characterization of Greater-Than-Class C Low-Level Radioactive Waste, Volume 1: Sealed Sources Held by Specific Licenses, DOE/LLW-163, 1993.

7. F. Feizollahi and D. Shropshire, Waste Management Facilities Cost Information Report for Greater-Than-Class C and DOE Equivalent Special Case Waste, EGG-WM-10701, July 1993. 